\section{Akimova 0.} Kravchenko 0.

\title{
DEVELOPMENT OF A METHOD FOR SELECTING A WAY OF RAW MATERIAL TRANSPORTATION FROM THE OFFSHORE DRILLING PLATFORM TO THE ONSHORE INFRASTRUCTURE
}

Об'єктом дослідження є процес транспортування добутих копалин від морських бурових платформ в шельфах морів до берегових резервуарів. Одним з найбільш проблемних місць є необхідність вибору засобів транспорту і способу транспортування добутих вуглеводнів від морських бурових платформ (МБП) до берегової інфраструктури.

Застосовуючи метод рівнозначних величин, було встановлено граничні значення використання трубопровідного транспорту в залежності від віддаленості морських видобувних платформ (МВБ) від берега.

В ході дослідження для вдосконалення організацї транспортування видобутих в шельфі морів вуглеводнів був розроблений алгоритм щодо обгрунтування способу транспортування в залежності від віддаленості МБП від берега. А також обгрунтований критерій вибору транспортного засобу та розглянута система показників для формування критерію. Методичний похід за вибором транспорту складається з наступних етапів:

- формуються показники капітальних, експлуатаційних та наведених витрат по кожному виду транспорту;

- визначається граничне значення показника приведених витрат для трубопровідного транспорту i для доставки шаттл-танкерами та за допомогою морських баржі-буксирних складів в залежності від віддаленості МБП від берега;

- виводиться критерій ефективності вибору виду транспорту;

- розраховується показник питомих витрат на морському і трубопровідному транспорті;

- визначається граничне значення використання одного з декількох видів транспорту.

Розроблений методичний підхід забезпечує обгрунтований підхід до вибору способу транспортування і виду транспорту при організащї доставки видобутої сировини від МБП до берегової інфраструктури, який забезпечує найменші питомі витрати з транспортування.

У порівнянні з аналогічними відомими методами, які застосовуються для вибору транспорту при наземному видобутку і транспортуванні, в морсъкому нафтовидобувному бізнесі подібні методи не застосовувалися.

Ключові слова: трубопровідний транспорт, судна-кабелеукладальники, доставка шаттл-танкерами, морсъкі бурові платформи, берегова інфраструктура, доставка барже-буксирними суднами.

\section{Introduction}

According to [1], by the end of 2017, global oil consumption increased by $1.8 \%$ or 1.7 million barrels per day, which is higher than the average of $1.2 \%$ over the past 10 years. Oil production increased by 0.6 million barrels per day. While maintaining the existing rates of oil and gas consumption, it will be enough for more than 54 and 52 years respectively, and taking into account the annual increase in world proven reserves of oil and gas due to the discovery of new fields both on land and at sea, hydrocarbon raw materials will be enough for humanity for a longer period. However, it is becoming more and more difficult to produce oil and gas every year. World oil production on land from fields with traditional reservoirs decreases by an average of $2-6 \%$ per year [2].

In order to meet the growing demand for energy, oil and gas companies increasingly have to introduce deposits into the development, from which it is difficult to extract reserves. These are offshore and offshore fields. For their cost-effective and environmentally safe operation requires the creation of new and continuous improvement of existing techniques and production technologies.

Today, $20 \%$ of world oil reserves and $45 \%$ of gas reserves are located on the world shelf. Most of the large reserves of natural gas were found in the open sea, especially on the deep and deeper shelf. Thus, the number of oil and gas platforms in 2010 amounted to 270 units, and in 2030 this number will be 618 units [3].

According to the French Petroleum Association (IFP EN) [4], the most promising areas for offshore oil and gas fields are the shelves of Brazil and West Africa, the continental margins of East Africa, especially in Mozambique and Tanzania. There are also many other opportunities in the Gulf of Mexico, the Mediterranean, Australia and the Arctic region.

In Ukraine, oil and gas production on the shelves of the seas is organized by Ukrgasvydobuvannya, which expects to start exploratory drilling on the Black Sea shelf in 2019-2020. And to go into industrial production in the 
beginning of 2021 by 2020 , Ukrgasvydobuvannya plans to invest 3 billion USD in the purchase and modernization of new equipment for oil and gas [5].

Based on the foregoing, the study is relevant, concerning the decision on the choice of method of transporting hydrocarbons from offshore drilling platforms to onshore reservoirs in the development of deposits in the shelf of the seas.

\section{The object of research and its technological audit}

The object of research is the process of transportation of mined minerals from offshore drilling platforms (ODP) in the sea shelves to onshore reservoirs.

The following technical means are used to deliver the extracted oil and gas from the extraction site to the onshore infrastructure:

- piping system;

- shuttle tanker;

- barge-towing vessels.

Currently, pipeline systems are widely used in the development of offshore oil and gas fields with a diameter of up to $1.220 \mathrm{~mm}$ at depths of up to $130 \mathrm{~m}$. Pipe lay vessels for depths of up to $600 \mathrm{~m}$ are designed. For this purpose, pipelay vessels (PV), a specialized vessel intended for laying underwater pipelines, are used. The pipelay vessel body has a simplified shape. Sometimes barges and vessels of other types refit in pipelay vessels. Perspective hull catamaran type or with stabilizing columns, especially for operation in areas with harsh weather conditions.

The technology of laying the underwater pipeline with pipelay vessels is in building it up by successive welding of the pipe sections on the deck. At shallow depths, a curvilinear descender is used to move the pipeline from the deck to the seabed, through which the pipeline is extended from the stern of the ship to the bottom as new pipe sections are welded. With an increase in the depth of the sea at the stern of the vessel, an additional hinge support stringer is installed to support the pipeline during its downward movement and to prevent its large bends when leaving the court.

A shuttle tanker, also called the Floating Pipeline, is used to transport crude oil from oil platforms to oil storage tanks and refineries onshore. As a rule, shuttle tankers are equipped with a sophisticated specialized cargo system located in the bow of the vessel, which makes it possible to receive oil from offshore facilities even in severe weather conditions. Shuttle tankers are distinguished by the presence of two or three bow thrusters, as well as stern thrusters, and are provided with an adjustable pitch propeller. The hull design is significantly enhanced. The length can be about $230-270 \mathrm{~m}$. These tankers have more stringent requirements and standards that meet the offshore industry.

The barge-towing vessels (BTV) of the marine destination use an innovative semi-rigid «sea» clutch, which remains operable at a wavelength of up to $7 \mathrm{~m}$. For the delivery of hydrocarbons from the ODP to the onshore infrastructure, specialized gas-carrying barges and barge bunker are used.

When using the BTV, it is necessary to apply a qualitatively new level of organization of work when transporting hydrocarbons in the shelf of the seas, namely, when one pusher serves $2-3$ barges. This approach is called «dropand-swop» $[6]$.

One of the most problematic places is the need to choose the means of transport and the method of transporting the extracted hydrocarbons from offshore drilling platforms to the onshore infrastructure.

\section{The aim and objectives of research}

The aim of research is development of a method approach to substantiating the method of transporting oil from offshore drilling platforms in the sea shelves to onshore facilities.

To achieve this aim it is necessary to perform the following objectives:

1. To determine the criteria for selecting the technical means for the delivery of hydrocarbons from the ODP to the onshore infrastructure.

2. To form a criterion for choosing the method of transportation and technical means.

\section{Research of existing solutions of the problem}

Issues related to the choice of transporting oil from the production sites in the shelf of the seas to the processing sites were considered in the works of many scientists. Thus, in [7], a method for choosing a mode of transport for transporting oil for export was considered. In this case, the criteria take into account the capital costs of the purchase or construction of the means of transporting oil for export during its surface production. In this work it is indicated that one should consider several or a whole range of options for delivery methods only by numbered them according to an increase in capital or operating costs and consider options in which the increase in capital expenditures is compensated by a decrease in operational costs. At the same time, the work does not take into account that the choice of technical means should be carried out not by absolute, but by relative indicators, such as cost price or reduced costs. In [8], mathematical modeling was developed for the composition of the shuttle tankers, the barge-towing structure, the main transport pipeline, the single-point offshore mooring and the floating storage. At the same time, the reduced costs are accepted as the main criterion for optimality, but only the method of building ships is considered.

Criteria for the selection of options on sea transport are formed by a system of economic indicators. In [9] it is emphasized that the choice of the mode of transport is carried out according to relative economic indicators. At the same time, in the theoretical aspect, to achieve an optimal result, the criteria are either maximized or minimized.

The main directions of development of technology for the extraction of oil and gas in the shelves of the seas were considered in [10]. At the same time, not enough attention is paid to the choice of the method of transportation of carbohydrates from offshore drilling platforms to the onshore infrastructure.

The cyclical work of the barge-towing vessels is reviewed in source [6], but it lacks the methodology for calculating BTV performance indicators on a cyclical basis. The practical aspect of oil transportation by pipeline transport 
in the shelf of the seas was considered in [11]. It was determined that the speed of transportation depends on the viscosity of the oil, which in turn depends on the temperature in the pipeline.

The general theory of stocks in the offshore industry is considered in [12]. However, due attention to the definition of criteria for selecting the method of transportation of mined raw materials is not given. Methods for selecting the optimal variant of oil and gas field platforms for the development of the shelf were considered in [13]. In particular, in this work, the priority was given to hydrometeorological, engineering-geological, geological, technological, industrial and environmental factors affecting the choice of the type of marine oil and gas producing hydraulic structures. However, the method of transportation is considered as a factor that influences the choice of platforms. And in [14] it was shown that the design of the offshore oil and gas hydraulic engineering structure has a multi-purpose character, which should be carried out as a multi-criteria optimization process using the following main criteria, such as «functionality», «economy», «strength», «safety», «environmental friendliness». But it is not disclosed what indicators these criteria are measured.

The development of technologies and technical means for the extraction of oil and gas in offshore Arctic fields are considered in [15]. This paper presents the main pipeline systems for the delivery of hydrocarbons from offshore Arctic fields and identifies the main problems of their design and construction. But the work does not pay attention to other ways of delivering raw materials from the ODP to the onshore infrastructure.

The assessment of the economic efficiency of forms of attracting investment in the search, exploration and production of oil and gas was carried out using the developed technology of strategic management of the development of an oil and gas company based on approved «target tree» schemes [16]. However, in work [16] investment in technical means is considered without preliminary type of funds being used.

In conditions of the fact that both oil and gas are extracted in the shelf of the seas from the ODP, the approaches to the organization of transportation of gases by sea transport were studied, revealed in studies [17]. The method of gas transportation proposed in these studies makes it possible to abandon the ship installation for gas recondensation, which allows considering the organization of gas delivery to barge-towing vessels. But in these studies there is no justification for the delivery of gas depending on the ODP distance.

Thus, the results of literary analysis suggest that studies to substantiate the method of transporting oil from offshore drilling platforms in the sea shelves to onshore facilities are promising and require further study.

\section{Methods of research}

For making decisions on the choice of the method of transportation of hydrocarbons from the ODP to the onshore infrastructure, use the methods of options, or mathematical methods of optimization.

The choice of a particular mode of transport for the transportation of hydrocarbons from the place of production to the offshore onshore infrastructure refers, as a rule, to a multi-criteria task [18-20].
When solving a multi-criteria task, it is often necessary to normalize (norm) the criteria, that is, to bring all the criteria $f_{k}(X)$ to a single scale and dimensionless form. The most frequently used replacement of criteria with their dimensionless relative values:

$$
\lambda_{k}(X)=\frac{f_{k}(X)}{f_{k}^{*}},
$$

where $f_{k}^{*}=\max _{X \in D} f_{k}(X)$.

Normalized criteria have two important properties: first, they are dimensionless quantities, and, secondly, they satisfy the inequality $0 \leq \lambda_{k}(X) \leq 1$ for any $X \in D$. These properties allow to compare the criteria among themselves [21-23].

The method used to reduce a multi-criteria task to a single-criterion one is in singling out one (main, main) criterion F1 and strive to turn it into a maximum (minimum), and impose only some restrictions on the remaining criteria F2, F3 ... Fm any given values. Thus, the idea of the main criterion method is that individual criteria are usually unequal between themselves (some of them are more important than others) and this allows to single out the main criterion, and consider other criteria as additional, related. Specific values of these additional constraints can be established, for example, using statistical methods, or expertly on the basis of informal considerations. This distinction allows to formulate problems of multicriteria optimization as the problem of finding the conditional extremum of the main criterion.

However, this method has a number of fundamental flaws. First of all, this method greatly simplifies the structure of the original problem, does not take into account the difference in the values of the criteria, moved into the category of restrictions. In addition, a rather difficult task is the formulation of restrictions on the values of less important criteria [24].

\section{Research results}

To determine the criterion for the choice of transportation method, it is necessary to form an indicator of unit expenses for each delivery method, depending on the distance from the ODP to the OI (onshore infrastructure). To do this, let's define and analyze technical means for each mode of delivery of hydrocarbons from the ODP to the onshore infrastructure (Table 1).

There are two ways to acquire technical equipment for the transportation of hydrocarbons - this is rent and purchase. With the pipeline method of transportation, two types of capital investment are the lease of a pipelay vessel and the purchase of a pipe. When using barge-towing vessels and a shuttle tanker, one of the possible ways is considered - rent or purchase (Fig. 1).

Accordingly, when purchasing all three means of transportation, as a criterion for choosing a method of transportation, it is advisable to use the reduced cost indicator, which consists of the specific operating costs and specific capital investments.

The general formula for determining the cost of shipping is:

$$
R_{g e n}=C_{w} \cdot t_{w}+C_{l} \cdot t_{l},
$$

where $C_{w}, C_{l}$ - the daily cost of the vehicle under way and laying, respectively, USD/day; $t_{w}, t_{l}-$ the time of the vehicle trip, day. 
Advantages and disadvantages of methods for transporting minerals from offshore drilling platforms to onshore reservoirs

\begin{tabular}{|c|c|c|c|}
\hline $\begin{array}{l}\text { The method } \\
\text { of transportation } \\
\text { of hydrocarbons } \\
\text { from offshore } \\
\text { drilling platforms } \\
\text { to the onshore } \\
\text { infrastructure }\end{array}$ & $\begin{array}{l}\text { Technical } \\
\text { means involved } \\
\text { in transporta- } \\
\text { tion }\end{array}$ & The advantages of transportation & The disadvantages of transportation \\
\hline Pipeline & $\begin{array}{l}\text { Pipelay vessel } \\
\text { Pipes for trans- } \\
\text { portation }\end{array}$ & $\begin{array}{l}\text { Does not require payments for the lease of the pipe. } \\
\text { Only the pipelay vessel is rented. } \\
\text { Does not depend on weather conditions }\end{array}$ & $\begin{array}{l}\text { Used at depths up to } 600 \mathrm{~m} \text {. } \\
\text { Restriction on the maximum transportation distance. } \\
\text { Large one-time investment in the purchase of the } \\
\text { pipe and its equipment. } \\
\text { Impossibility of use after deposit closure }\end{array}$ \\
\hline $\begin{array}{l}\text { Barge-towing } \\
\text { vessels }\end{array}$ & $\begin{array}{l}\text { Specialized } \\
\text { barges: gas- } \\
\text { carrying barges } \\
\text { and barge } \\
\text { bunkers, tows }\end{array}$ & $\begin{array}{l}\text { Barges and tows can be rented or purchased. } \\
\text { Low running costs. } \\
\text { Small crew size ( } 2-3 \text { ). } \\
\text { Short parking time to replace barges in the port. } \\
\text { Ability to work at wave heights up to } 2 \mathrm{~m}\end{array}$ & $\begin{array}{l}\text { Dependence on weather conditions. } \\
\text { Limited work distance from shore. } \\
\text { Capacity of one barge in one pass is limited (5 thou- } \\
\text { sand tons) }\end{array}$ \\
\hline Shuttle tankers & Shuttle tankers & $\begin{array}{l}\text { Can be rented or purchased. } \\
\text { Load capacity is limited by the characteristics of the site. } \\
\text { There are no restrictions on the maximum distance of transportation. } \\
\text { Decrease in specific operational expenses at increase in distance } \\
\text { of transportation }\end{array}$ & $\begin{array}{l}\text { The high cost of the rental rate. } \\
\text { The high cost of investment in construction. } \\
\text { The high cost of explant expenses }\end{array}$ \\
\hline
\end{tabular}

Options for the acquisition of vehicles for the transport of hydrocarbons from mining sites to the onshore infrastructure

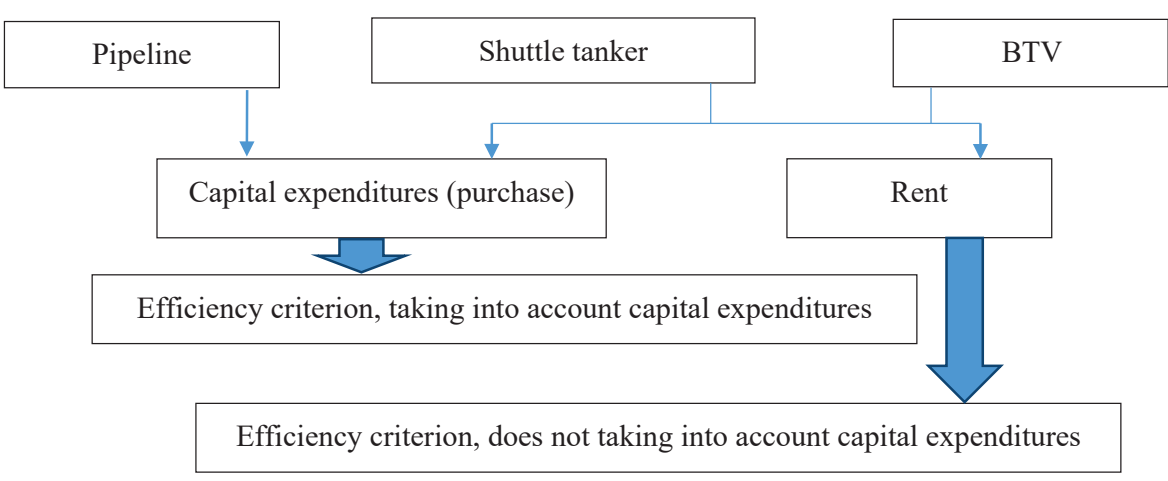

Fig. 1. Stages of formation of the criterion for choosing the method of transportation: BTV - barge-towing vessel

Let's consider the costs for the case of the acquisition of vehicles in two ways: subject to purchase and subject to rent.

Daily expenses under way consist of the following elements:

$$
C_{w}=C_{f i x}+C_{w}^{\mathrm{var}}+C_{w}^{a d m},
$$

where $C_{f i x}$ - daily fixed expenses, USD/day $C_{w}^{\text {var }}$ - daily variables under way, USD/day; $C_{w}^{a d m}$ - administrative daily variables, USD/day.

Daily expenses for laying:

$$
C_{l}=C_{f i x}+C_{\mathrm{var}}^{l}+C_{l}^{a d m},
$$

where $C_{l}^{\text {var }}$ - daily variable expenses for laying, USD/day.

Direct fixed costs $C_{f i x}$ are defined as the sum of the items:

- when buying vehicles:

$$
C_{f i x}=K_{i n s} \cdot C_{d}+C_{r}+C_{d e l}+C_{c},
$$

where $K_{\text {ins }}-$ coefficient taking into account the cost of insurance of the vessel; $C_{d}, C_{r}, C_{d e l}-$ daily expenses for depreciation, repair, delivery, USD/day; $C_{c}$ - average daily expenses for the maintenance of the crew, USD/day;

- when renting vehicles:

$$
C_{f i x}^{\prime}=f_{r}+C_{d e l}+C_{c}+C_{p o r t},
$$

where $f_{r}$ - the rental rate, USD/day. Variable expenses are the same for both ways of purchasing:

- under way:

$$
C_{\mathrm{var}}^{w}=q_{f}^{w} \cdot P_{f}^{w} \cdot k_{l},
$$

where $q_{f}^{w}$ - fuel consumption under way, t/day; $P_{f}^{w}-$ fuel price, USD/t; $k_{l}$ - lubrication coefficient;

$$
\text { - laying: }
$$

$$
C_{\mathrm{var}}^{l}=q_{f}^{l} \cdot P_{f}^{l} \cdot k_{l},
$$

where $q_{f}^{l}$ - fuel consumption during the laying, t/day; $P_{f}^{l}$ - fuel price, USD $/ \mathrm{t} ; k_{l}$ - lubrication coefficient.

Total expenses for renting ships:

$$
R_{g e n}^{\prime}=C_{w}^{\prime} \cdot t_{w}+C_{l}^{\prime} \cdot t_{l}
$$

As a criterion for choosing a vehicle for transporting raw materials from the offshore drilling platform (ODP) to the onshore infrastructure (OI), let's the unit expenses indicator, in USD per ton-mile.

Let's consider the formation of the indicator of specific costs for each method of delivery of raw materials: pipeline, barge-towing and shuttle tankers. 
For the pipeline method of delivery, a pipelay vessel is used, which is purchased on a time-charter basis, and capital investments directly for the purchase of a pipe.

The capital costs of laying the pipeline along the bottom of the shelf include: the cost of equipment, materials, works on the construction of the object.

Previously, to calculate the expenses it is necessary to determine the diameter of the pipe, which depends on the planned capacity of the field. The capital expenses of the linear part for a given diameter of the pipeline and the capital expenses of pumping stations, as well as operating costs for repairs, are determined. Then the indicator of reduced expenses is formed.

Specific capital expenses for pipeline transport [6]:

$$
K_{p}=C_{p} L
$$

where $C_{p}$ - specific cost of the pipeline, USD $/ \mathrm{m} ; L$ - pipeline length of the, $\mathrm{m}$.

Thus, as the selection criterion for the pipeline method of transportation, an indicator of reduced costs in ton-miles is taken, which is determined by the formula:

$$
S_{Q L}^{\prime}=\frac{R_{g e n}^{\prime}+E \cdot 1000 \cdot K_{p}}{Q L}, \mathrm{USD} / \mathrm{t}-\mathrm{m}
$$

where $Q$ - amount of hydrocarbons, which it is planned to produce per year, $\mathrm{t}$; $L$ - the total mileage of tonnage from the ODP to the onshore infrastructure and in the opposite direction, m; $E$ - coefficient of specific capital investments.

Or, if substitute the expression (10) into the formula and execute the transformations, let's obtain the following type of criterion:

$$
S_{Q L_{T}}^{\prime}=\frac{R_{g e n}^{\prime}}{Q L}+\frac{C_{p}}{Q}, \mathrm{USD} / \mathrm{t}-\mathrm{m} .
$$

When transporting a shuttle tanker, and barge-towing vessels, let's consider only the purchase of ships for rent.

Unit expenses indicator:

- for shuttle tankers:

$$
S_{Q L_{s-t}}^{\prime}=\frac{R_{g e n_{s-t}}^{\prime}}{Q L},
$$

where $R_{g e n_{s-t}}^{\prime}$ - the general expenses of the shuttle tanker, operated under the rent;

- for barge-towing vessels, general expenses are determined not during the voyage, but for the cycle of work with one barge [6], therefore the formula will have the following form:

$$
R_{\text {gen } n_{B T V}}^{\prime}=R_{\text {gen }_{T o w}}^{\prime}+R_{\text {gen }_{B a r g e}}^{\prime},
$$

where $R_{\text {gen } \text { Tow }_{\text {ow }}}^{\prime}-$ general expenses of the tow, USD; $R_{\text {gen } \text { Barge }_{\text {B }}}^{\prime}-$ general expenses of barge, USD:

$$
\begin{aligned}
& R_{\text {genBVT }}^{\prime}=n_{v}\left(C_{w}^{\prime \text { Tow }} \cdot t_{w}^{\text {Tow }}+C_{l}^{\prime \text { Tow }} \cdot t_{l}^{\text {Tow }}\right) \cdot n^{\text {Tow }}+ \\
& +C^{\prime \text { Barge }} \cdot T_{c} \cdot n^{\text {Barge }},
\end{aligned}
$$

where $C_{w}^{\prime \text { Tow }}, C_{l}^{\prime \text { Tow }}$ - cost of under way and laying maintenance of the tows, USD/day, which is calculated by the formulas (3), (4); $C^{\text {Barge }}$ - cost of barge maintenance, USD/day; $n^{\text {Tow }}, n^{\text {Barge }}$ - the number of barges and tows necessary to work on the cycle; $n_{v}$ - the number of tow voyages per cycle; $T_{c}$ - the cycle time of the barge-towing pair, day.

Cost of barge maintenance:

$$
C_{w}^{\text {Barge }}=C_{f i x}+C_{w}^{a d m} .
$$

The number of barges and tows necessary to work on a cycle is determined when the barge-towing vessels operate on the «drop \& swop» principle [6]. The work is organized in such a way that all vessels and loading equipment at the berths can work without interruptions, and the ratio is observed:

$$
\left[n_{b}\right]+\left[N_{O D P}\right]=\left[n_{T}\right]
$$

The number of barges tanks can be calculated by the formula:

$$
n_{T}=\frac{Q_{t} \rho}{q r_{T}}
$$

where $Q_{t}$ - the amount of hydrocarbons to be transported during the year, t; $q$ - the capacity of one tank, t; $\rho$ the product density, $\mathrm{t} / \mathrm{m}^{3} ; r_{T}$ - cycle (number of voyages per year) of a tank barge; $N_{O D P}-$ the number of offshore drilling platforms.

The number of cycles is determined by the formula:

$$
r_{T}=\frac{365}{T_{T}},
$$

where $T_{T}$ - the total turnover time of one tank per day.

The cycle period is determined by the variant of the work of the barge-towing vessel. Under the option of «2 tows +3 barges», the cycle time is calculated by the formula:

$$
T_{T}=\left(3 \cdot T_{\text {WTivith BTempty }}+3 \cdot T_{\text {wT Twith BTloaded }}\right)+T,
$$

where $T_{\mathbb{W}_{T} \text { with BTempty }}, \quad T_{\mathbb{W}_{T} \text { auth BToaded }}-$ the transition time of the tow with an empty and loaded barge-tank, respectively; 3 - means that during the cycle the barge makes three voyages in each direction; $\Delta T$ - the difference between the laying of the tow and the tank:

$$
T=\left(3 \cdot\left(T_{l_{\text {load } . T}}-T_{w_{T} \text { wath BTempty }}\right)+3 \cdot\left(T_{l_{\text {unload } . T}}-T_{w_{T \text { wath BTload }}}\right)\right),
$$

where $T_{l_{\text {load. } .}}, T_{l_{\text {unboul. } T}}$ - the time of the tank laying under loading and unloading, day.

Thus, the criterion for determining the efficiency of transportation by barges towing vessels is as follows:

$$
\begin{aligned}
& S_{B T V}^{\prime}=\frac{R_{\text {gen BTV }}^{\prime}}{Q L}= \\
& =\frac{n_{v}\left(C_{w}^{\prime \text { Tow }} \cdot t_{w}^{\text {Tow }}+C_{l}^{\prime \text { Tow }} \cdot t_{l}^{\text {Tow }}\right) \cdot n^{\text {Tow }}+C^{\prime \text { Barge }} \cdot T_{c} \cdot n^{\text {Barge }}}{Q L} .
\end{aligned}
$$


In formula (22) let's substitute the value of time on the move:

$$
t_{w}=\frac{l_{c}}{V_{o}},
$$

where $l_{c}$ - the transportation distance with cargo, $\mathrm{km}$; $V_{o}$ - operational speed of tows, $\mathrm{km} /$ day.

Laying time is determined by the formula:

$$
t_{l}=\frac{2 Q}{\bar{M}_{w}},
$$

where $\bar{M}_{w}$ - the weighted average handling rates of ships and barges in ports, tons/day.

For shuttle tanker:

$$
\begin{aligned}
& \frac{C^{\prime \text { Barge }} \cdot 3 \cdot \frac{l_{c}}{V_{o t}} \cdot n^{\text {Barge }}}{Q L}= \\
& =\frac{n_{v} \cdot n^{\text {Tow }}\left(C_{w}^{\prime \text { Tow }}+3 C_{w}^{\prime \text { Tow }}\right)}{Q V_{o}}+\frac{2 n_{v} \cdot n^{\text {Tow }} \cdot C_{l}^{\text {Tow }}}{\bar{M}_{w} L}= \\
& =S_{B T V}^{w}+S_{B T V}^{l},
\end{aligned}
$$

where $S_{B T V}^{w}$ - the under way component of the cost of transportation for BTV, USD/t-m; $S_{B T V}^{l}$ - the parking component of the cost of transportation, for BTV, USD/t-m:

$$
S_{B T V}^{w}=\frac{n_{v} \cdot n^{T o w}\left(C_{w}^{\prime T \text { Tow }}+3 C_{w}^{\prime \text { Tow }}\right)}{Q V_{o}} .
$$

Laying component of transportation costs:

$$
S_{B T V}^{l}=\frac{2 n_{v} \cdot n^{T_{w w}} \cdot C_{l}^{\prime \text { Tow }}}{\bar{M}_{w} L} .
$$

Similarly, let's transform the unit expenses formula for a shuttle tanker. Let's substitute in the formula the value of time under way and in the laying and denote the amount of cargo through the net load capacity, let's obtain the following formula:

$$
S_{s-t}^{\prime}=\frac{C_{w}}{Q V_{o}}+\frac{2 C_{l}}{\bar{M}_{w} L}=S_{s-t}^{\prime w}+S_{s-t}^{\prime l},
$$

where $S_{s-t}^{\prime w}$ - the under way component of the cost of transportation for BTV, USD/t-m; $S_{s-t}^{\prime \prime}$ - the laying component of the cost of transportation for BTV, USD/t-m.

Let's define the limit value of the distance between barge-towing delivery method and the shuttle tanker using the method of equivalent values. Let's compare the cost of transporting raw materials by BTV and shuttle tanker:

$$
\begin{aligned}
& S_{s-t}^{\prime w}+S_{s-t}^{\prime l}=S_{B T V}^{w}+S_{B T V}^{l}, \\
& S_{s-t}^{\prime w}-S_{B T V}^{w}=S_{B T V}^{l}-S_{s-t}^{\prime l}, \\
& \frac{C_{w}}{Q V_{o}}-\frac{n_{v} \cdot n^{T o w}\left(C_{w}^{\prime T o w}+3 C_{w}^{\prime B a r g e}\right)}{Q V_{o}}= \\
& =\frac{2 n_{v} \cdot n^{T o w} \cdot C_{l}^{\prime T o w}}{\bar{M}_{w} L}-\frac{2 C_{l}}{\bar{M}_{w} L} .
\end{aligned}
$$

After the transformations, let's obtain the critical value $L$, in which the shuttle tankers should be used:

$$
L=\frac{Q V_{o}\left(2 n_{v} \cdot n^{\text {Tow }} \cdot C_{l}^{\prime \text { Tow }}-2 C_{l}\right.}{\bar{M}_{w}\left(C_{w}-n_{v} n^{\text {Tow }}\left(C_{w}^{\prime \text { Tow }}+3 C_{w}^{\prime \text { Barge }}\right)\right.} .
$$

The choice between pipeline transport and marine is done graphically. At the first stage, the distance at which it is advisable to use one of the three delivery methods should be determined. To do this, for a given volume of production per year, it is necessary to cross out the graphs of the dependence of unit expenses in ton-meters (Fig. 2).

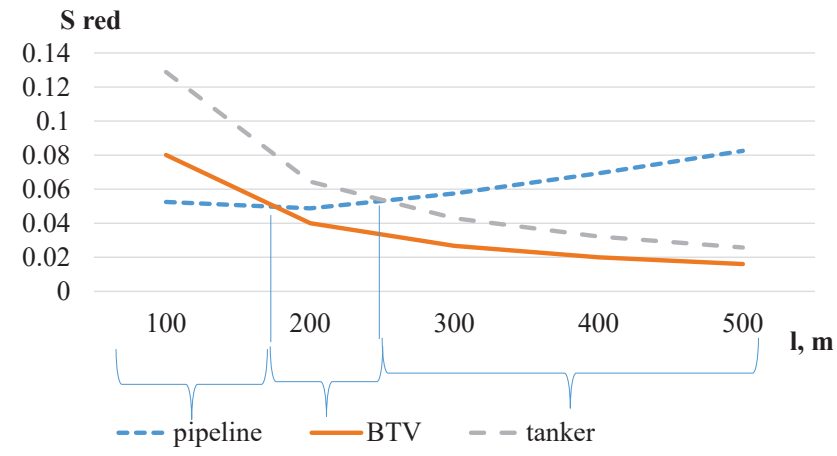

Fig. 2. An example of calculating the dependence of unit expenses on the distance between offshore drilling platforms and onshore infrastructure

As can be seen from Fig. 2, at the distance of the ODP up to $180 \mathrm{~m}$ under other permissible conditions, only pipeline transport should be used. At a distance of 180 to $250 \mathrm{~m}-$ pipeline transport and barge-towing vehicles, at a distance of more than $250 \mathrm{~m}$ - shuttle tankers or BTV. For distances from 250 to and more - BTV and shuttle tankers.

Thus, to justify the type of technical equipment in one of the three options for the delivery of hydrocarbons from the ODP to the onshore infrastructure, the choice occurs among the technical and operational characteristics of one type of vehicle. For example, in the first section with the option of delivery by pipeline transport, the choice occurs only among the options for the diameters of the pipe and the pipelay vessel.

In the case of a barge-towing delivery method, options for selecting technical means are among the technical and operational characteristics of barges and tows.

When using shuttle tankers - among the technical and operational characteristics of vessels of this type.

To do this, it is necessary to determine the variant with the highest value of the indicator corresponding to the worst variant, and then determine in relation to it the dimensionless criteria for other types of transportation:

$$
\lambda_{k}=\frac{S_{\text {red } k}}{\max S_{\text {red }}},
$$

where $k$ - type of transportation method of hydrocarbons from the ODP to the onshore infrastructure, namely: BTV; shuttle tanker; pipeline.

\section{SWOT analysis of research results}

Strengths. The efficiency of the operation and maintenance of facilities located in the shelves of the seas depends on the proper organization of the work of vehicles at the planning stage. The organization of the delivery of hydrocarbons from 
the ODP to OI according to the developed method allows to choose the best delivery method for the best technical and operational characteristics of vehicles. Compared with peers, depending on the performance criterion, this allows to:

- substantiate the technical and operational charac-

teristics of vehicles with each method of delivery of

hydrocarbons from the ODP to the OI;

- minimize the cost of delivering hydrocarbons from

the ODP to the OI;

- minimize the cost of purchasing vehicles to organize the delivery of hydrocarbons from the ODP to the OI;

- minimize the cost of transportation of hydrocarbons from the ODP to the OI.

Weaknesses. The weaknesses in the developed methodological approach are:

- only one selection criterion was considered - minimum reduced costs;

- requires additional calculations to substantiate the technical and operational characteristics of vehicles with each method of transportation.

Opportunities. In a further improvement of the developed methodological approach to determine the method of delivery of hydrocarbons from the ODP to the OI with a larger number of vehicle options, an economic-mathematical model should be developed for various performance criteria.

The introduction of the developed methodological approach at the enterprise will allow the company to reduce the cost of transportation of hydrocarbons from ODP to the OI. This is achieved by choosing the best delivery method and the best vehicles for each method. A methodical approach developed can be interesting for both Ukrainian and foreign companies.

Threats. When introducing the developed methodological approach to the choice of the delivery method, it is especially important for the company to determine the mode of transportation for a known sense of the ODP distance from the coast. To do this, it is necessary to additionally develop a system of factors influencing the definition of the delivery method.

The implementation of the proposed methodological approach does not require additional costs for the company.

An analogue of the developed methodological approach can be methods of justifying the type of vessel for servicing the ODP.

\section{Conclusions}

1. It is shown that as a criterion for choosing the method of delivery of hydrocarbons, a complex indicator of reduced costs for each technical means is used. This indicator is made up of the cost of transportation of hydrocarbons and the specific investment for the purchase of a vehicle. The indicator takes into account two ways to purchase vehicles: rent and purchase.

2 . The study adopted as a selection criterion for a multiobjective task a dimensionless indicator $0 \leq \lambda_{k}(X) \leq 1$, which allows not only to choose the method of transportation, but also to choose technical tools from the corresponding method according to their technical and operational characteristics.

\section{References}

1. BP Statistical Review of World Energy. 2018. URL: https:// www.bp.com/content/dam/bp/business-sites/en/global/corporate/pdfs/energy-economics/statistical-review/bp-stats-review2018-full-report.pdf

2. BP Statistical Review of World Energy. 2017. URL: https:// www.bp.com/content/dam/bp-country/de ch/PDF/bp-statistical-review-of-world-energy-2017-full-report.pdf
3. Wang B. World GDP should double by 2030 and World Trade, Shipping, Ports and Supply Chain will match // Nextbigfuture. 2014. URL: https://www.nextbigfuture.com/2014/10/worldgdp-should-double-by-2030-and.html

4. 2018 ERP Report. Panorama Consulting Solutions. 2018. URL: https://cdn2.hubspot.net/hubfs/2184246/2018\%20ERP \%20Report.pdf

5. Ukraina nashla krupnoye mestorozhdeniye gaza v Chernom more // Ukraina.ru. 2016. URL: https://ukraina.ru/news/ 20161213/1017997667.html

6. Tsyklycheskaia rabota // ARTICOUPLE. 2010. URL: http:// www.articouple.com/rus/20-cyclic.html

7. Sarkiev V. M. Ekonomicheskoe obosnovanie vybora vida transporta pri neftianykh logisticheskikh operaciiakh // Vestnik Dagestanskogo gosudarstvennogo tekhnicheskogo universiteta. Tekhnicheskie nauki. 2010. Issue 18. P. 179-186.

8. Petrov M. P. Proektirovanie morskoi transportnoi sistemy dlia obsluzhivaniia neftianykh mestorozhdenii Severnogo Kaspiia: Abstract PhD theses. Astrakhan, 2010.

9. Akimova O. V. Osnovy teorii transportnykh protsesiv ta system: textbook. Odessa: ONMA, 2015. 395 p.

10. Speight J. G. An Introduction to Petroleum Technology, Economics, and Politics. Salem: Scrivener Publishing, 2011. 327 p.

11. John G. Offshore Pipeline Transport Of Waxy Crude Oils Offshore South East Asia Show. Singapore, 1986. doi: http:// doi.org/10.1002/9781118192528

12. Chaib-Draq B., Muller J. P. Multiagent based Supply Chain Management. Berlin: Springer, 2006. 450 p. doi: http://doi.org/ 10.1007/978-3-540-33876-5

13. Mirzoev F. D. ogli Metody vybora racionalnogo varianta neftegazopromyslovykh platform dlia osvoeniia shelfa: Abstract $\mathrm{PhD}$ theses. Moscow, 2003. URL: http://www.dissercat.com/content/ metody-vybora-ratsionalnogo-varianta-neftegazopromyslovykhplatform-dlya-osvoeniya-shelfa\#ixzz4QamyhhcU

14. Ermakova A. I. Optimalnoe proektirovanie morskikh neftegazovykh sooruzhenii: Abstract doctor theses. Moscow, 2000. URL: http://www.dissercat.com/content/optimalnoe-proektirovanie-morskikh-neftegazovykh-sooruzhenii\#ixzz4QanUv6qE

15. Dvorianinov N. E. Razvitie tekhnologii i tekhnicheskikh sredstv dlia dobychi nefti i gaza na morskikh shelfakh: Abstract PhD theses. Ufa, 2008. URL: http://www.dissercat.com/content/ razvitie-tekhnologii-i-tekhnicheskikh-sredstv-dlya-dobychinefti-i-gaza-na-morskikh-arktiche\#ixzz4QaoK8ad5

16. Kim A. S. Ocenka ekonomicheskoi effektivnosti form privlecheniia investicii v poiski, razvedku i dobychu nefti: Abstract $\mathrm{PhD}$ theses. Moscow, 2004. URL: http://www.dissercat.com/content/ otsenka-ekonomicheskoi-effektivnosti-form-privlecheniya-investitsii-v-poiski-razvedku-i-doby\#ixzz4QaoW04zL

17. Vasserman A. A., Shutenko M. A. Sovershenstvovanie khraneniia i regazifikacii szhizhennykh gazov pri ikh morskoi dostavke // Tekhnicheskie gazy. 2012. Issue 3. P. 24-29.

18. Vinnikov V. V. Ekonomika predpriiatiia morskogo transporta (ekonomika morskikh perevozok): textbook. Odessa: Latstar, 2001. 416 p.

19. Voevudskii E. N., Sokolova O. V. Sistema modelei opisaniia processov upravleniia na morskom transporte: textbook. Moscow: CRIA «Morflot», 1981. 103 p

20. Voevudskii E. N. Upravlenie na morskom transporte. Moscow: Transport, 1993. 366 p.

21. Shikin E. V., Shikina G. E. Issledovanie operacii: textbook. Moscow: TK Velbi, Izd-vo Prospekt, 2006. 281 p.

22. Emelianov C. B., Larichev O. I. Mnogokriterialnye metody priniatiia reshenii. Moscow: Znanie, 1985. 29 p.

23. Larichev O. I. Teoriia i metody priniatiia reshenii. Moscow: Logos, 2002. 392 p.

24. Shtoier R. Mnogokriterialnaia optimizaciia. Teoriia, vychisleniia i prilozheniia. Moscow: Radio i sviaz, 1992. 504 p.

Akimova Olga, PhD, Associate Professor, Department of Fleet Operation and Technology of Maritime Transportation, Educational Scientific Institute of Maritime Business, Odessa National Maritime University, Ukraine, e-mail: Olga.onmu@gmail.com, ORCID: http:// orcid.org/0000-0001-9007-0894

Kravchenko Alexandra, Senior Lecturer, Department of Fleet Operation and Technology of Maritime Transportation, Educational Scientific Institute of Maritime Business, Odessa National Maritime University, Ukraine, e-mail: alliyya@i.ua, ORCID: http://orcid.org/ 0000-0001-5920-927X 